
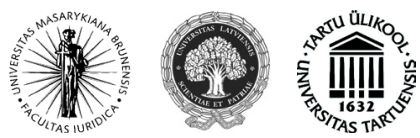

ISSN 1392-6195 (print) ISSN 2029-2058 (online) JURISPRUDENCIJA JURISPRUDENCE 2014, 21(2), p. 615-629.

\title{
TEISMŲ PRAKTIKOS AKTUALIJOS BAUDŽIAMOSIOSE BYLOSE DĖL KORUPCINIO POBŪDŽIO NUSIKALSTAMŲ VEIKŲ
}

\author{
Artūras Petkus \\ Mykolo Romerio universiteto Teisès fakulteto \\ Baudžiamosios teisès ir proceso institutas \\ Ateities g. 20, LT-08303 Vilnius, Lietuva \\ Tel.: (+370 5) 2714584 \\ Elektroninis paštas: apetkus@mruni.eu
}

Pateikta 2014 m. gegužès 15 d., parengta spausdinti 2014 m. gegužès 23 d.

doi:10.13165/JUR-14-21-2-14

\section{Ivadas}

2011 metais buvo pakeista visuma Lietuvos Respublikos baudžiamojo kodekso (toliau - BK) normų. Kai kurie svarbūs pakeitimai padaryti ir XXXIII skyriaus straipsniuose, numatančiuose baudžiamąją atsakomybę už nusikaltimus ir baudžiamuosius nusižengimus valstybès tarnybai ir viešiesiems interesams. Minètų pakeitimų esmé - „siekis tinkamai suderinti baudžiamojo įstatymo nuostatas su Europos Sąungos institucijų ataskaitose pateiktomis rekomendacijomis, taip užtikrinant baudžiamojo ịstatymo veiksmingumą <...>"1. Nors teisès normos kūrimas, svarstymas bei priemimas yra labai svarbus procesas, tačiau įstatymo įsigaliojimas pats savaime dar negarantuoja tinkamo normų veikimo ir socialinių santykių reguliavimo veiks-

1 Lietuvos Respublikos teisingumo ministerija. Teikimas dèl teisès aktų projektų. 2010-10-01, Nr. (1.5.)7R-8417.

Jurisprudencija/Jurisprudence

(C) Mykolo Romerio universitetas, 2014

(C) Mykolas Romeris University, 2014
ISSN 1392-6195 (print), ISSN 2029-2058 (online) http://www.mruni.eu/lt/mokslo_darbai/jurisprudencija/ http://www.mruni.eu/en/mokslo_darbai/jurisprudencija/ 
mingumo. Kita labai svarbi stadija - teisès taikymas - tiesiogiai siejasi su teisingumo igyvendinimu, todèl teismų praktika, jos nuoseklumas ir turinio kokybè tampa viena pagrindinių veiksmingumo prielaidų, taikant baudžiamąji ịstatymą.

Darbe analizuojama Lietuvos teismų praktika baudžiamosiose bylose dèl nusikalstamų veikų, tiesiogiai siejamų su korupcija. Lyginant kyšininkavimo (BK 225 str.) ir papirkimo (BK 227 str.) dinamiką per pastarąji dešimtmetį, atkreiptinas dèmesys i tai, kad užregistruotų ir ištirtų papirkimo atvejų Lietuvoje per minètąjj laikotarpi padaugèjo beveik 10 kartų, tuo tarpu užregistruotų ir ištirtų kyšininkavimo atvejų beveik 2 kartus². Šiuo atveju negalima daryti skubotų išvadų, kad asmenys ėme daug dažniau papirkinèti valstybės pareigūnus arba jiems prilygintus asmenis, nes tokios dinamikos prielaidomis gali būti teisèsaugos institucijų prioritetinių veiklos krypčių perskirstymas bei kiti veiksniai, kurie nèra šio darbo objektas. Minètų nusikalstamų veikų dinamika suformuoja poreikị panagrinèti probleminius teismų jurisprudencijos aspektus, kurie siejasi tiek su praktiniais baudžiamosios teisès taikymo iššūkiais (korupcinio pobūdžio nusikalstamų veikų kvalifikavimas, ịrodymų ir argumentų vertinimas ir t. t.), tiek su kriminologijos mokslo iššūkiais (valstybės institucijų reakcijos ị korupcinio pobūdžio nusikalstamas veikas prevencinis poveikis ir pan.).

Tyrimo tikslas - išnagrinèti kai kurių korupcinio pobūdžio nusikalstamų veikų kvalifikavimo ypatumus, išanalizuoti skirtingų instancijų teismų argumentus bei pateikti įžvalgas dẻl tyrimo objektu pasirinktų Baudžiamojo kodekso normų taikymo veiksmingumo.

Tyrimo objektas yra Lietuvos teismų igyvendinama baudžiamosios teisės taikymo praktika vykdant teisingumą Lietuvos Respublikos baudžiamojo kodekso XXXIII skyriuje numatytų nusikalstamų veikų kontekste.

Atliekant tyrimą taikyti analizès, apibendrinimo ir lyginamasis metodai.

\section{Korupcinio pobūdžio nusikalstamų veikų subjekto samprata}

Teismų praktikoje yra daug probleminių specialaus subjekto interpretavimo aspektų. Nors Baudžiamojo kodekso normos turi būti taikomos sistemiškai, tačiau teismų praktikoje išskiriami tam tikri valstybės tarnautojo ar jam prilyginto asmens sąvokos ypatumai. Pažymètina, kad BK 230 straipsnio 1-3 dalyse pateiktas oficialus sąvokų išaiškinimas leidžia nustatyti valstybès tarnautojo ir valstybės tarnautojui prilyginamo asmens požymius, pagal kuriuos sprendžiama, ar baudžiamaja teisine prasme asmuo yra valstybès tarnautojas (BK 230 straipsnio 1 dalis), ar valstybès tarnautojui prilyginamas asmuo (BK 230 straipsnio 2 ir 3 dalis). Vien tai, kad minètu asmenų požymiai yra apibrěžti viename BK 230 straipsnyje, neleidžia daryti išva-

2 Duomenys apie nusikalstamumą Lietuvos Respublikoje. Užregistruotos ir ištirtos nusikalstamos veikos (Forma 1 Ž) 2004-2012 m. [interaktyvus]. [žiūrèta 2014-03-18]. <http://www.nplc. lt:8000/asis/>. 
dos, kad valstybės tarnautojui prilyginamas asmuo yra laikomas valstybės tarnautoju. Tokị aiškinimą pagrindžia ne tik BK 230 straipsnio 1-3 dalyse nurodyti skirtingi požymiai, bet ir BK XXXIII skyriuje numatytos nusikalstamų veikų dispozicijos, kuriose, be valstybès tarnautojo, tiesiogiai nurodomas ir kitas - valstybès tarnautojui prilyginamas, asmuo (BK 225-229 straipsniai). Valstybės tarnautojo ir jam prilyginamo asmens sąvokų oficialus išaiškinimas yra pateiktas BK XXXIII skyriuje ir minèti asmenys yra šiame skyriuje numatytų nusikalstamų veikų specialieji subjektai, nes BK 230 straipsnio 1 dalyje tiesiogiai nurodoma, kad joje yra kalbama apie šiame skyriuje nurodytus valstybès tarnautojus ${ }^{3}$.

Pagal baudžiamąji ịstatymą valstybès tarnautojai yra asmenys, dirbantys valstybės tarnyboje, - valstybès politikai, viešojo administravimo valstybės tarnautojai pagal Valstybės tarnybos ịstatymą bei kiti asmenys, kurie dirbdami valstybès ar savivaldybių institucijose ar ịstaigose, teisminèse, teisėsaugos, valstybės kontrolès bei priežiūros ir joms prilygintose institucijose atlieka valdžios atstovo funkcijas arba turi administracinius igaliojimus, taip pat oficialūs kandidatai $\mathfrak{i}$ tokias pareigas (BK 230 straipsnio 1 dalis). Be to, valstybės tarnautojui prilyginamas asmuo, kuris dirba bet kokioje valstybinèje, nevalstybinèje ar privačioje įstaigoje, įmonëje ar organizacijoje ar verčiasi profesine veikla ir turi atitinkamus viešojo administravimo igaliojimus ar teikia viešąsias paslaugas, išskyrus ūkines ar technines funkcijas atliekantị asmeni (BK 230 straipsnio 3 dalis). Pažymètina, kad valstybès tarnautojo ir jam prilyginto asmens sąvokos išaiškinamos vadovaujantis ir kitais teisès aktais, nustatančiais jų funkcijas, teises, pareigas ir igaliojimus ${ }^{4}$.

Pavyzdžiui, Všt „(duomenys neskelbtini)“ i̇statuose, patvirtintuose Vilniaus miesto savivaldybès tarybos $2006 \mathrm{~m}$. balandžio $26 \mathrm{~d}$. sprendimu Nr. 1-1138, nurodyta, kad tai yra viešoji ịstaiga, kurios steigèja ir savininkè yra Vilniaus miesto savivaldybès taryba. Pagrindinis šios įstaigos tikslas - teikti viešas paslaugas, vykdant savivaldybei nuosavybès teise priklausančių gyvenamųjų patalpų (socialinio būsto, bendrabučių) administravimo ir priežiūros funkcijas (Įstatų 2.1 punktas). İstatuose apibrèžta ir įstaigos veiklos rūšys, pavyzdžiui, gyvenamųjų patalpų remonto darbų organizavimas (2.3.13 punktas), gyvenamųjų patalpų statybos užsakovo procedūrų vykdymas (2.3.17 punktas). İstatuose ịtvirtinta ir ịstaigos vadovo, kaip vienasmenio ístaigos valdymo organo, kompetencija, nurodomi jo administraciniai ir kiti igaliojimai. Pavyzdžiui, 7.2.1 punkte nurodyta, kad ịstaigos vadovas „organizuoja İstaigos veiklą ir veikia Istaigos vardu santykiuose su kitais asmenimis, sudaro visus reikiamus sandorius, išskyrus sandorius, kuriuos sudaryti draudžia İstaigos vadovo ar jo igalioto asmens priimti sprendimai“. Kaip matyti iš bylos medžiagos, V. K. nusikals-

3 Lietuvos Aukščiausiojo Teismo Baudžiamųjų bylų skyriaus 2013 m. kovo 19 d. nutartis baudžiamojoje byloje Nr. 2K-160/2013.

4 Lietuvos Aukščiausiojo Teismo Baudžiamųjų bylų skyriaus 2008 m. spalio 28 d. nutartis baudžiamojoje byloje Nr. 2K-P-181/2008. 
tamos veikos padarymo metu V. G. dirbo Všst „(duomenys neskelbtini)“, kuri teikia viešąsias paslaugas, direktoriumi ir turèjo administracinius igaliojimus. Taigi pagal BK 230 straipsnio 1 dali V. G. buvo valstybès tarnautojas. Tai, kad V. G. mano, jog jis nèra valstybès tarnautojas, veikos kvalifikacijai reikšmès neturi ${ }^{5}$.

Atkreiptinas dėmesys, kad Lietuvos aukščiausiojo Teismo praktika dèl asmens pripažinimo valstybès tarnautojui prilygintu asmeniu susiduria su tam tikrais teisinio vertinimo iššūkiais. Antai M. M. buvo nuteistas ir pagal BK 228 straipsnio 2 dali (piktnaudžiavimas) už tai, kad, būdamas privataus juridinio asmens (UAB „A“) direktoriumi, piktnaudžiavo jam suteiktais direktoriaus igaliojimais siekdamas turtinès naudos, t. y. imonés vardu pagamino netikra dokumenta, suklastojo tikrus dokumentus ir pasinaudodamas jais padejo $U A B$, „A“ naudai išvaistyti $U A B$, „B“ turta. ${ }^{6}$

Lietuvos Aukščiausiojo Teismo Baudžiamųjų bylų skyriaus plenarinè sesija argumentavo, $\mathrm{kad}<\ldots>$ administracinių igaliojimų turèjimas pagal BK 230 straipsnio 3 dali i iš esmès reiškia tai, kad asmuo, dirbdamas juridiniame asmenyje ar versdamasis profesine veikla, turi tam tikrus igaliojimus jam nepavaldiems asmenims ar kitokius administracinius iggaliojimus, susijusius su viešojo administravimo veikla. Tokiais ịgaliojimais gali būti ir tie ịgaliojimai, kurie padeda užtikrinti juridinio asmens savarankišką veiklą (struktūros tvarkymas, dokumentų, personalo, turimų materialinių ir finansinių išteklių valdymas), kad jis galètų tinkamai atlikti savo funkcijas. Paprastai šie iggaliojimai susiję su tuo, kad asmuo turi teisę veikti juridinio asmens vardu. Būtent teisè veikti juridinio asmens ar kitos organizacijos vardu, tai dar vienas iš igaliojimų, kurị turintis asmuo pagal BK 230 straipsnio 3 dalị gali būti prilyginta valstybès tarnautojui.?

Nutartyje nurodoma, kad valstybès tarnautojui BK 230 straipsnio 3 dalies prasme gali būti prilyginamas ne bet kuris asmuo, kurio darbas ar profesinè veikla reiškia viešųjų paslaugų (kaip tai suprantama pagal Viešojo administravimo įstatymą) teikimą. Šis darbas ar profesinè veikla turi būti susijusi su teisiškai reikšmingų veiksmų atlikimu, t. y. iš esmès tokių, kuriais būtų siekiama užtikrinti viešajj̨ interesą ir kurių neatlikimas ar netinkamas atlikimas reikštų viešojo intereso pažeidimą.

Sprendžiant klausimą dèl to, ar asmuo BK 230 straipsnio prasme laikytinas valstybės tarnautojui prilygintu asmeniu nepakanka vien tik to, kad toks asmuo formaliai atitinka BK 230 straipsnio 3 dalyje įvardytus požymius - dirba juridiniame asmenyje (kitoje organizacijoje) ar verčiasi profesine veikla ir turi administracinius ịgaliojimus, arba turi teisę veikti šio juridinio asmens (kitos organizacijos)

5 Lietuvos Aukščiausiojo Teismo Baudžiamųjų bylų skyriaus $2008 \mathrm{~m}$. spalio 28 d. nutartis baudžiamojoje byloje Nr. 2K-P-181/2008.

6 Lietuvos Aukščiausiojo Teismo Baudžiamųjų bylų skyriaus $2014 \mathrm{~m}$. kovo 13 d. nutartis baudžiamojoje byloje Nr. 2K-P-89/2014.

7

Ibid. 
vardu, arba teikia viešąsias paslaugas. Taip pat turi būti nustatyta, kad tokia asmens veikla yra susijusi su viešojo intereso užtikrinimu ir šios veiklos nevykdymas ar netinkamas vykdymas (pvz., piktnaudžiaujant savo padėtimi, viršijant suteiktus igaliojimus) reikštų viešojo intereso pažeidimą. Kasacinès instancijos teismo praktikoje yra konstatuota, kad privataus ūkio subjekto vadovas ar kitas darbuotojas gali būti prilygintas valstybès tarnautojui, tačiau tokia išvada turi būti daroma ịvertinus ne tik formalų einamų pareigų atitikimą BK 230 straipsnyje nurodytiems požymiams, bet ir jo padarytų veiksmų reikšmingumą valstybės tarnybai ar viešiesiems interesams (kasacinè nutartis baudžiamojoje byloje Nr. 2K-7-251/2013). Priešingu atveju, t. y. valstybès tarnautojui prilygintu asmeniu pripažįstant privataus ūkio subjekto vadovą ar kitą jo darbuotoją, formaliai atitinkantị BK 230 straipsnio 3 dalyje ịtvirtintus požymius, ir nevertinat jo veiklos reikšmingumo užtikrinant viešuosius interesus ar valstybès tarnybai, būtų iškreipta nusikalstamų veikų valstybès tarnybai ir viešiesiems interesams esmė, BK XXXIII skyriuje ịtvirtintų normų paskirtis. Šiame kontekste pažymėtina ir tai, kad reikalavimai asmenims, dirbantiems valstybès tarnyboje ir privačiame juridiniame asmenyje, daugeliu aspektu iš esmès skiriasi (pvz., priimant asmenị $\mathfrak{i}$ darbą valstybès tarnyboje, skirtingai nei priimant dirbti privačiame juridiniame asmenyje, paprastai turi būti skelbiamas viešasis konkursas, skiriasi valstybės tarnautojų ir privačių juridinių asmenų darbuotojų drausminès (tarnybinès) atsakomybès pagrindai ir principai.). Taigi ir dèl to vien tik formalus privačių juridinių asmenų vadovų, kitų jų darbuotojų prilyginimas valstybès tarnautojui neatitiktų nusikalstamų veikų valstybės tarnybai ir viešiesiems interesams prasmès, BK XXXIII skyriuje įtvirtintų normų paskirties. ${ }^{8}$

Šiame kontekste pažymètina, kad UAB „B“ vykdė didmeninę prekybą langų ir durų furnitūra, o UAB „A“ teikè automobilių remonto ir patalpų nuomos paslaugas. Taigi minètų bendrovių veikla nelaikytina tokia, kuri reikštų viešojo intereso igyvendinimą. M. M. nusikalstamais veiksmais turtinė žala buvo padaryta privačiam ūkio subjektui ir tai irgi savaime nereiškia, kad taip buvo pažeisti viešieji interesai. Be to, paminètina ir tai, kad tokie M. M. veiksmai nagrinejjamoje byloje buvo įvertinti baudžiamuoju teisiniu aspektu, juos pagal BK pripažinus padejjimu iššvaistyti svetimą didelès vertès turtą ir dokumentų klastojimu. Atsižvelgiant ị išdèstytus argumentus konstatuotina, kad M. M. nelaikytinas BK 228 straipsnio 2 dalyje numatytos nusikalstamos veikos subjektu. ${ }^{9}$

Apibendrinant Lietuvos Aukščiausiojo Teismo praktiką nagrinejjamu klausimu reikia konstatuoti, kad valstybès tarnautojui prilyginto asmens formuluotès turinys yra nagrinėjamas konkrečios bylos apimtyje. Šiuo atveju bylos duomenimis nebuvo pagrịstas ryšys tarp teisiamojo veiksmų ir žalos viešiesiems interesams. Tačiau Teismo argumentaciją vertinant bendrame teismų praktikos kontekste, manytina, kad ši

$9 \quad$ Ibid. 
nutartis bus prielaida intensyvioms diskusijoms dèl termino „valstybès tarnautojui prilygintas asmuo" turinio ir teisinio vertinimo.

\section{Kyšio dalyko, dydžio ir vertès nustatymo bei įvertinimo problematika}

Kyšis yra bet kokios turtinès ar kitokios asmeninès naudos sau ar kitam asmeniui (materialios ar nematerialios, turinčios ekonominę vertę rinkoje ar tokios vertès neturinčios) forma išreikštas neteisètas ar nepagrịstas atlygis už pageidaujamą valstybès tarnautojo ar jam prilyginto asmens teisètą ar neteisètą veikimą arba neveikimą vykdant iggaliojimus (BK 230 straipsnio 4 dalis). İstatymų leidejjas aukštu apibendrinimo lygiu nurodo sąlygas, kurioms esant tam tikra nauda gali būti pripažįstama kyšiu. Teismų praktikoje turtinès naudos siekimas suprantamas kaip bet kokios turtinio pobūdžio naudos siekimas (pvz.: neatlygintinai naudotis įmonès turtu, teikiamomis paslaugomis, įsigyti turtą sumažintomis kainomis, gauti jo iš kitų asmenų) ne tik sau, bet ir savo giminèms, šeimos nariams ar kitiems asmenims, su kuriais kaltininkas susijęs draugystės, partnerystės ar kitokiais ryšiais ${ }^{10} .<\ldots>$ Byloje nustatyta ir teismu sprendimuose nurodyta, kad Ž. Ž. siekdamas asmeninès turtinès naudos, büdamas Jonavos rajono savivaldybès tarybos narys, Sveikatos, ekologijos ir socialiniu reikalu komiteto pirmininkas, be to, jis buvo ir komisijos viešajam pirkimui organizuoti („Sajūdžio" aikštès detaliojo plano rengimo) narys, t. y. eidamas aukštas pareigas savivaldybeje, piktnaudžiaudamas einamu pareigu svarba, valdžios atstovo statusu, asmeniniais ryšiais su A. V. ir pažintimi su UAB „Statva“ darbu vykdytoju S. M., kreipési ị A. V. prašydamas jo susitarti su S. M. neatlygintinai atvežti i jo (Ž. Ž.) namu valda žvyro ir granito skaldos. A. V., dirbdamas Jonavos rajono savivaldybés administracijos Remonto, ükio ir statybos skyriaus vyriausiuoju specialistu, turédamas administracinius igaliojimus - $2008 \mathrm{~m}$. rugpjūčio $18 \mathrm{~d}$. Jonavos rajono savivaldybès administracijos direktoriaus įsakymu paskirtas atsakingu už Jonavos miesto „Sajūdžio“ aikštès rekonstrukcijos darbu vykdymą bei priežiūrą, pasinaudodamas šiomis pareigomis bei igaliojimais, neteisètai nurode S. M., nefiksuojant dokumentais, pakrauti granito skaldos ir UAB "Statva“ transportu nuvežti bei neatlygintinai iškrauti Ž. Ž. gyvenamojo namo kieme; teismų nuosprendžiuose nurodyti konkretūs aktyvūs A. V. (taip pat ir Ž. Ž.) veiksmai, kuriais jis sieke ir pasieke turtinès naudos su juo tarnybinio pobudžio ryšiais susijusiam Ž. Ž. Taip pat nustatyta, kad A. V. veike tyčia, suprasdamas ir norédamas elgtis priešingai tarnybos interesams siekdamas turtinès naudos. Taigi, nuteistasis piktnaudžiavo einamomis pareigomis siekdamas neteisètu tikslu, todèl A. V. gynejo nurodyta aplinkybe, kad tarp A. V. ir S. M. nebuvo tiesioginio pavaldumo santykiu, - nešalina baudžiamosios atsakomybès ir veikos kvalifikavimui neturi

10 Lietuvos Aukščiausiojo Teismo Baudžiamųjų bylų skyriaus 2013 m. balandžio 9 d. nutartis baudžiamojoje byloje Nr. 2K-191/2013. 
reikšmès. Apeliacinès instancijos teismas padarè motyvuotas ir teisingas išvadas, kad A. V. veika (esant ja sukeltiems BK 228 straipsnio 1 dalyje nurodytiems padariniams) užtraukia baudžiamąją atsakomybę.

Teisejjų kolegija konstatuoja, kad pagal byloje nustatytas faktines aplinkybes, apibūdinančias piktnaudžiavimą siekiant turtinès naudos, baudžiamasis ịstatymas pritaikytas tinkamai - nuteistųjų Ž. Ž. ir A. V. veikos pagal BK 228 straipsnio 2 dali kvalifikuotos teisingai ${ }^{11}$.

Bylose dèl nusikalstamų veikų, numatytų BK 225 bei 227 straipsniuose, proceso dalyviai skirtingai interpretuoja kyšio dalyką. Antai Vilniaus apygardos teismo 2008 m. kovo 20 d. nuosprendžiu A. Z. ir A. J. nuteisti pagal BK 24 straipsnio 4 dali, 22 straipsnio 1 dali, 227 straipsnio 2 dali už tai, kad organizavo pasikèsinima papirkti valstybès tarnautoja V. D., o D. L. nuteistas pagal BK 22 straipsnio 1 dali, 227 straipsnio 2 dali už pasikèsinimą papirkti valstybès tarnautoją V. D. Nusikalstama veika padaryta šiomis faktinèmis aplinkybèmis: laikotarpiu nuo $2003 \mathrm{~m}$. gegužès mèn. pradžios iki 2003 m. gegužès 20 d. (ikiteisminio tyrimo ir teismo tiksliai nenustatyta diena), (duomenys neskelbtini), A. Z., siekdamas teiseto (duomenys neskelbtini) miesto savivaldybés tarybos nario $V$. D. veikimo vykdant igaliojimus, t. y. kad jis $2003 \mathrm{~m}$. birželio $11 \mathrm{~d}$. (duomenys neskelbtini) miesto savivaldybès tarybos posėdžio metu vyksiančiuose (duomenys neskelbtini) miesto mero rinkimuose balsuotų už A. Z., nurodè A. J. per V. D. pažistama D. L. pasiūlyti V. D. kyši - sudaryti su juo tariama didelés vertés projektavimo darbu sandori, realiai neketinant sukurti teisiniu padarinių šio sandorio šalims, bet suteikiant galimybe gauti materialinį atlygi už šiu didelès vertès projektavimo darbu tariama atlikimą ${ }^{12}$.

Priešingai, nei savo kasaciniuose skunduose teigia nuteistieji (duomenys neskelbtini), pramogų parko projektavimo darbų sandoris numatant galimybę išmokèti 45000 Lt avansą teisingai teismo pripažintas kyšiu. Baudžiamosios atsakomybès nustatymas už kyšininkavimui priskiriamas veikas (BK 225-227 straipsniai) BK skyriuje „Nusikaltimai ir baudžiamieji nusižengimai valstybės tarnybai ir viešiesiems interesams“ reiškia, kad įstatymų leidejjas, be kita ko, siekia užtikrinti sąžiningumo, teisètumo, nešališkumo, visų lygybès prieš įstatymą bei kitų konstitucinių principų reikalavimų laikymąsi valstybès tarnautojų ir jiems prilygintų asmenų veikloje bei apsaugoti juos nuo neteisèto, nepagrịsto turtinio poveikio, pažeidžiančio minètų principų reikalavimus ${ }^{13}$. Taigi kyšiu, kaip papirkimo dalyku, pripažistamas neteisètai duotas, siūlytas ar žadètas turtinis atlygis valstybės tarnautojui ar jam prily-

11 Lietuvos Aukščiausiojo Teismo Baudžiamųjų bylų skyriaus 2013 m. balandžio 9 d. nutartis baudžiamojoje byloje Nr. 2K-191/2013

12 Lietuvos Aukščiausiojo Teismo Baudžiamųjų bylų skyriaus 2009 m. vasario 10 d. nutartis baudžiamojoje byloje Nr. 2K-7-48/2009.

13 Lietuvos Aukščiausiojo Teismo Baudžiamųjų bylų skyriaus 2008 m. spalio 28 d. nutartis baudžiamojoje byloje Nr. 2K-P-181/2008. 
gintam asmeniui už pageidaujamą teisètą ar neteisètą veikimą ar neveikimą vykdant igaliojimus. Šio turtinio atlygio materialus pavidalas ir teisinè forma gali būti ịvairūs, tarp jų ir tariamos ar tikros civilinès sutartys su paperkamuoju. Pripažįstant duotą, siūlytą ar žadètą atlygị kyšiu svarbiausia yra tai, kad šis atlygis, nebūdamas oficialiai reglamentuojamų darbinių santykių dalis, siejamas būtent su valstybės tarnautojo ar jam prilyginto asmens igaliojimų vykdymu. Kolegija konstatuoja, kad teismas, nustatęs, kad (duomenys neskelbtini) pramogų parko projektavimo darbų sandoris su galimybe gauti avansą buvo siūlomas V. D. siekiant paveikti jo, kaip (duomenys neskelbtini) miesto savivaldybès tarybos nario, balsavimą per (duomenys neskelbtini) miesto mero rinkimus, pagrịstai pripažino, kad šis sandoris ir avansas buvo siūlomi kaip kyšis ${ }^{14}$.

Nepagrịstas yra ir nuteistųjų kasaciniuose skunduose pateiktas argumentas, kad jų veikose negalima ižžvelgti nei pasiūlymo, nei pažadèjimo duoti kyšĭ, nes V. D. nebuvo informuotas apie tai, kokio veikimo iš jo pageidaujama, o vien už motyvus ir tikslus bausti negalima. Kolegija, atmesdama šiuos argumentus, pažymi, kad tiek kyšio pasiūlymas, tiek jo pažadejjimas, kaip nusikalstamos veikos, gali būti padaryti ịvairiais būdais: žodžiu, raštu, veiksmu ir pan., ir šiomis veikomis siekiama informuoti valstybès tarnautoją ar jam prilygintą asmenį apie papirkejjo ketinimus atsilyginti už atitinkamą veikimą ar neveikimą (praeityje ar ateityje) vykdant ịgaliojimus. Teismo nustatyti D. L. veiksmai rengiant projektavimo darbų sutarties projektą, susitinkant su V. D. bei derinant su juo sutarties sąlygas, avanso sumokejjimo formą, pasirašant pačią sutartị, esant tyčiai šiuo būdu papirkti V. D., atitinka pasiūlymo ir pažadejjimo duoti kyší požymius. Teismo nustatyti A. Z. veiksmai nurodinejjant A. J., o šio veiksmai nurodinejant D. L., kad V. D. reikia kaip kyši pasiūlyti pasirašyti projektavimo darbų sutartį bei sumoketi 45000 Lt, kontroliuojant šio plano igyvendinimą ir koreguojant jo detales, atitinka organizavimo papirkti požymius ${ }^{15}$.

Kartais baudžiamojo proceso dalyviai skirtingai interpretuoja „didelès vertės kyšio“ sampratą. Nuteistujjų kasaciniuose skunduose yra ginčijama teismo išvada, kad V. D. buvo siūlomas didelès vertès kyšis, nes įvykio metu (2003 m. birželio mèn.) buvo mažesnis MGL dydis, ir ji padidinus kyšio dydis nebesiekia reikiamos 250 MGL dydžio vertès. Kolegija atmeta ši argumentą, nes apkaltinamojo nuosprendžio priemimo metu 1 MGL dydis buvo $130 \mathrm{Lt}$, taigi 250 MGL dydis atitinkamai buvo $32500 \mathrm{Lt}$. Nusikaltimo padarymo metu 250 MGL dydis buvo 31250 Lt. Tuo tarpu teismas nustatè, kad V. D. realiai buvo pažadètas 45000 Lt vertès kyšis, todèl išvada dèl didelès vertès kyšio yra visiškai pagrịsta imant kaip pagrindą tiek nusikaltimo padarymo, tiek nuosprendžio priemimo laiką ${ }^{16}$.

14 Lietuvos Aukščiausiojo Teismo Baudžiamųjų bylų skyriaus 2009 m. vasario 10 d. nutartis baudžiamojoje byloje Nr. 2K-7-48/2009.

15 Ibid.

16 Lietuvos Aukščiausiojo Teismo Baudžiamujų bylų skyriaus 2009 m. vasario 10 d. nutartis baudžiamojoje byloje Nr. 2K-7-48/2009. 
Paminėtina, kad baudžiamosiose bylose kyla sisteminio teisès normų taikymo ir aiškinimo klausimų. Štai kyšininkavimo, numatyto BK 225 straipsnyje, požymiai 1) kyšio prièmimas, 2) pažadas ji priimti, 3) susitarimas ji priimti, 4) reikalavimas ji duoti, 5) provokavimas ji duoti - istatymo dispozicijoje suformuluoti kaip alternatyvūs; baudžiamajai atsakomybei pagal ši Baudžiamojo kodekso straipsnị kilti pakanka, kad būtų padaryta bent viena šių veikų. Istatymo dispozicijoje nurodyti nusikalstamos veikos požymiai yra vienodos reikšmès, kiekvienas atskirai su kitais nusikalstamos veikos požymiais sudaro visą nusikalstamą veiką, todèl, jeigu kaltininkas padarè veiką, atitinkančią kelis įstatyme numatytus alternatyvius požymius, laikoma, kad padarytos ne kelios, o viena nusikalstama veika, kvalifikuojama pagal BK 225 straipsnio atitinkamą dalį. Kaip matyti iš bylos medžiagos, V. A. nuteistas už tai, kad, būdamas teismo nutartimi paskirtu bankrutuojančios UAB „Egivela“ administratoriumi, taigi būdamas valstybès tarnautojui prilygintu asmeniu, už neteisètą neveikimą vykdant ígaliojimus, t. y. tinkamai neorganizuoti administruojamos bendrovès ūkinès finansinès veiklos patikrinimo bei reikiamai nereaguoti ị paaiškèjusius pažeidimus, iš jo administruojamos bendrovès akcininko tiesiogiai reikalavo 60000 Lt kyšio ir susitarè dèl $50000 \mathrm{Lt}$ kyšio. Bylos medžiaga bei E. B. ir V. A. parodymai patvirtina, kad derybose dèl kyšio V. A. atsisake 60000 Lt reikalavimo ir susitarè dèl 50000 Lt dydžio kyšio, tai rodo, kad reikalavimas transformavosi ị konkretų susitarimą, todèl šiuo atveju apeliacinès instancijos teismas nuosprendyje pagrịstai pažymėjo, kad vien tik deklaratyvus pinigų, reikalaujamų kaip kyšis, sumos paminejjimas dar negali būti laikomas baigtu nusikaltimu, jeigu susitariama kitaip. Atsižvelgdama ị tai kasacinès instancijos teisejų kolegija neturi teisinio pagrindo nesutikti su skundžiamo nuosprendžio aprašomosios dalies pakeitimu, pašalinant konstatavimą, kad V. A. reikalavo iš E. B. $60000 \mathrm{Lt}$ dydžio kyšio ${ }^{17}$.

Tuo tarpu kitoje byloje suformuota atskiroji nuomonè, kurios vienu iš argumentų iškeliamas kyšio vertès klausimas, tačiau kiek kitokiame kontekste. Kauno apygardos teismo $2011 \mathrm{~m}$. kovo 21 d. nuosprendžiu E. V. nuteistas pagal BK 225 straipsnio 1 dali laisvès atèmimu vieneriems metams šešiems mènesiams atliekant bausmę pataisos namuose. Lietuvos apeliacinio teismo Baudžiamujų bylu skyriaus teiseju kolegija $2011 \mathrm{~m}$. liepos $14 \mathrm{~d}$. nuosprendžiu minèta Kauno apygardos teismo nuosprendi pakeité: pritaike BK 75 straipsnio 1 dali, 67 straipsnio 2 dalies 4 punktą, 71 straipsni ir E. V. paskirtos bausmés vykdymq atidejo vieneriems metams bei jam paskyrè baudžiamojo poveikio priemone - 15 MGL (1950 Lt) dydžio įmoka i nukentëjusiuju nuo nusikaltimu asmenu fonda ${ }^{18}$.

17 Lietuvos Aukščiausiojo Teismo Baudžiamųjų bylų skyriaus $2012 \mathrm{~m}$. gruodžio 18 d. nutartis baudžiamojoje byloje Nr. 2K-666/2012.

18 Lietuvos Aukščiausiojo Teismo Baudžiamujų bylų skyriaus teisejų kolegijos $2012 \mathrm{~m}$. vasario $7 \mathrm{~d}$. nutartis baudžiamojoje byloje Nr. 2K-24/2012. 
E. V. savo iniciatyva iš A. P. pareikalavo duoti 30000 Lt dydžio kyši, pažadèjo ji priimti ir prièmé 30000 Lt kyši už teisètą savo veikimą vykdant savo igaliojimus, kad A. P. bus paskirta kita kardomoji priemonè ir šis iš suemimo bus paleistas. Jis reikalavo, pažadèjo priimti ir prièmé didelès sumos kyšĭ, kuris tik labai nežymiai mažesnis už 250 MGL dydžio kyšį, kvalifikuojamą kaip sunkų nusikaltimą. Ši aplinkybė taip pat rodo didesni E. V. veikos pavojingumą ${ }^{19}$. A priori vertinant tokią nuomonę gali kilti mintis, kad yra siekiama bet kokiais argumentais „pritraukti“ sprendimą prie griežtesnès bausmės skyrimo, tačiau atkreiptinas dėmesys, kad tai nèra vienintelis vertinimą keičiantis argumentas. Kita vertus, atsiranda erdvès pamąstymams dèl būtinybès kiek įmanoma sistemiškiau vertinti bylos aplinkybes, nes konkrečiu atveju kyšio vertė gali būti santykinis, sisteminiame ịrodymų vertinime dalyvaujantis elementas, neturintis įtakos veikos kvalifikavimui, tačiau igalinantis parinkti ir skirti adekvatesnę baudžiamojo teisinio poveikio priemonę.

Santykinai naujas dalykas teismų praktikoje yra mažos vertės kyšis. Pagal BK 227 straipsnio 4 dalị atsako tas asmuo, kuris tiesiogiai arba netiesiogiai pasiūlè, pažadejo ar susitare duoti arba davė mažesnès negu 1 MGL vertės kyši valstybės tarnautojui ar jam prilygintam asmeniui arba trečiajam asmeniui už pageidaujamą valstybès tarnautojo ar jam prilyginto asmens teisètą arba neteisètą veikimą ar neveikimą vykdant igaliojimus. Taigi papirkimas objektyviai reiškiasi bent vieno iš alternatyvių veiksmų padarymu: kyšio pasiūlymu, pažadu ji duoti, susitarimu duoti kyši ar jo davimu. Kyši žadama, siūloma duoti ar jis duodamas už pageidaujamą valstybès tarnautojo (jam prilyginto asmens) teisètą arba neteisètą veikimą ar neveikimą vykdant igaliojimus. Kvalifikuojant asmens veiksmus pagal BK 227 straipsnį, esminę reikšmę turi ne tai, kieno naudai siūloma, žadama, susitariama duoti kyši ar jis yra duodamas (pvz., pinigai, kitos turtinès vertybes) - ar pačiam valstybès tarnautojui (jam prilygintam asmeniui), ar per valstybès tarnautoją kitam fiziniam, juridiniam asmeniui, o tai, ko siekiama tokiais veiksmais. Šiuo atveju būtina nustatyti, kad, siūlant, žadant, susitariant duoti ar duodant pinigus ar kitas turtines vertybes, valstybės tarnautoją (jam prilygintą asmenį) siekiama paveikti, kad jis, vykdydamas igaliojimus, elgtųsi taip, kaip to pageidauja papirkejjas. BK 227 straipsnyje numatyta nusikalstama veika padaroma tiesiogine tyčia. Nagrinejamos bylos kontekste pažymètina, kad sprendžiant asmens kaltumo dèl papirkimo (BK 227 straipsnis) klausimą reikia ịvertinti ne tik tai, kaip atitinkamus tokio asmens (papirkejo) veiksmus (pvz., perdavimą valstybės tarnautojui tam tikros pinigu sumos) suprato valstybès tarnautojas (jam prilygintas asmuo), bet ir nustatyti šio asmens ketinimą papirkti valstybės tarnautoją (jam prilygintą asmenị). Būtent turi būti ịrodyta, kad papirkejjas suvokia, jog jis valstybès tarnautojui

19 Lietuvos Aukščiausiojo Teismo teisèjo Vytauto Greičiaus atskiroji nuomonè dèl Lietuvos Aukščiausiojo Teismo Baudžiamųjų bylų skyriaus teisẻjų kolegijos 2012 m. vasario 7 d. nutarties Nr. 2K-24/2012. 
neteisètai duoda pinigus (kitas turtines vertybes) už tai, kad šis veiktų (neveiktų) jo naudai, ir nori, kad valstybès tarnautojas priimtų kyši bei patenkintų jo interesus ${ }^{20}$.

Atkreiptinas dèmesys, kad apie 48 proc. visų už papirkimą per 2008-2010 m. I pusmetị nuteistų asmenų buvo nuteista pagal BK 227 straipsnio 3 dalị, numatančią baudžiamąją atsakomybę už mažesnès negu 1 MGL vertès kyšio pasiūlymą, pažadejimą arba davimą valstybès tarnautojui, jam prilyginamam asmeniui arba tarpininkui $^{21}$. Tuo tarpu pagal BK 225 straipsnio 4 dalị 8 valstybès tarnautojai ar jiems prilyginti asmenys (apie 18 proc.) nuteisti už baudžiamojo nusižengimo padarymą, kai kyšio vertė neviršijo $1 \mathrm{MGL}$ dydžio sumos ${ }^{22}$. Apibendrinant teismų praktiką kyšininkavimo bylose, kai kyšis yra mažesnis nei $1 \mathrm{MGL}$, reikia paminèti, kad šios normos atsiradimas gali būti vertinamas kaip kraštutinè priemoné, kurios ịstatymo leidèjas èmèsi reaguodamas ị Lietuvos korupcijos žemèlapio ir kitų korupcijos tyrimų duomenis, kurie rodo, kad praktikoje labai didelè dalis atvejų, kai kyšio suma neviršija 130 litų, o tokius atvejus asmenys nèra linkę vertinti kaip kyšio davimą. Kita vertus, didelis tokių atvejų paplitimas ir tikètinas intensyvumas daro žalą valstybès institucijų prestižui, krenta visuomenès pasitikejjimas šių institucijų darbuotojais, dèl to mažèja valstybès institucijų veiklos efektyvumas, daroma žala valstybès valdymo sistemai.

\section{Teisèto ir neteisèto veikimo/neveikimo turinys ir teisinis vertinimas}

Praktikoje pasitaiko atvejų, kai valstybès tarnautojas ar jam prilygintas asmuo pagal teisés normomis nustatytus ipareigojimus privalo vienu metu vykdyti keletą funkcijų arba vienų pareigų vykdymo metu atsiranda kitos pareigos. Tokiais atvejais iškyla klausimas dèl veikos kvalifikavimo pagal BK 225, 227 straipsnio 1 arba 2 dalis, kadangi, viena vertus, subjektas vykdo pareigas, t. y. veikia teisètai, tačiau, kita vertus, nuo tam tikro momento nevykdo savo pareigu, tokiu būdu elgdamasis neteisètai.

Pirmosios instancijos teismo nuosprendžiu su pakeitimais, padarytais apeliacinès instancijos teismo nuosprendžiu, A. B. ir P. S. nuteisti už tai, kad, büdami valstybès tarnautojai, A. B., dirbdamas Kauno apskrities VPK Kauno m. (duomenys neskelbtini) tyrèju, o P. S. - Kauno apskrities VPK Kauno m. (duomenys neskelbtini) postiniu, vykdydami jiems suteiktus igaliojimus, važinėdami tarnybiniu automobiliu po jiems

20 Lietuvos Aukščiausiojo Teismo Baudžiamųjų bylų skyriaus 2013 m. gruodžio 10 d. nutartis baudžiamojoje byloje Nr. 2K-540/2013.

21 Teismų praktikos skiriant bausmes už nusikalstamas veikas valstybės tarnybai ir viešiesiems interesams (Baudžiamojo kodekso 225, 226, 227 ir 228 straipsniai) tyrimas [interaktyvus]. [žiūrèta 2013-12-19]. <http://www2.lat.lt/lat_web_test/4_tpbiuleteniai/senos/nutartis.aspx? id= 34914>.

Ibid. 
priskirta teritorija ir veikdami bendrininku grupe, provokavo duoti kyšius ir juos priemè, bütent:

2008 m. gruodžio 29 d., laikotarpiu nuo 18 val. 08 min. iki 18 val. 13 min., Kauno apskrities VPK tarnybiniame automobilyje „VW Golf“ (valst. Nr. (duomenys neskelbtini), stovejusiame Kauno r., Karmèlavos sen., Naujasodžio k., (duomenys neskelbtini), provokavo duoti kyši ir, B. J. tiesiogiai pasiülius jiems 400 Lt kyši už neteisètą neveikimą, t. y. už B. J. nepatraukima administracinèn atsakomybèn dèl jo galimo padaryto administracinès teisés pažeidimo, numatyto Lietuvos Respublikos administraciniu teisés pažeidimu kodekso (toliau - ATPK) $51^{3}$ straipsnio 1 dalyje, ji iš B. J. savo naudai priemé (byloje nustatyta dar 14 nusikalstamos veikos epizodų - aut. past.) ${ }^{23}$.

Šioje byloje nuteistųjų veikos buvo kvalifikuotos tiek pagal BK 225 straipsnio 2 dali, tiek pagal 225 straipsnio 4 dali. Apeliacinés instancijos teismo nuosprendyje išsamiai išnagrinèti BK 225 straipsnyje numatytų nusikalstamų veikų požymiai ir padaryta pagrịsta išvada, kad pagal byloje surinktus duomenis kiekvienu atveju duoti kyšius buvo provokuojama, reikalaujama ir kyšiai buvo priimami už ịtariamą galimą padarytų administracinių teisès pažeidimų neužfiksavimą. Tai, ar kyšius davę asmenys procesų metu dèl administracinių teisès pažeidimų padarymo būtų buvę pripažinti kaltais padarę atitinkamus pažeidimus, ar tokie procesai būtų pasibaigę kitokiais sprendimais, įtakos nuteistųjų veikų kvalifikavimui neturi. Ittakos veikų kvalifikavimui neturi ir A. B. bei jo gynejjo kasaciniame skunde nurodomas argumentas, kad pažeidimų prevenciją nuteistieji vykdè teisètai, veikdami pagal Policijos veiklos įstatymą. Nuteistieji kaltais pripažinti ne dèl prevencinių funkcijų atlikimo, o dèl nereagavimo ịstatymų nustatyta tvarka ị tikètina padarytus pažeidimus - visais kyšio prièmimo atvejais kyšius davusiems asmenims buvo paaiškinta, kad jie yra padarę pažeidimus ir kad išvengti administracinès atsakomybės gali už atlygi pareigūnams, t. y. nuteistieji leido suprasti, kad jie veiks neteisètai nefiksuodami padarytų pažeidimų, jei už pareigos traukti pažeidejjus atsakomybèn nevykdymą bus duotas kyšis. Baudžiamosios atsakomybės pagal BK 225 straipsnio 2 dalị taikymui jokios reikšmès neturi tai, kaip būtų pasibaigusios kyšius davusių asmenų bylos dẻl administracinių teisès pažeidimų padarymo, jei nuteistieji kyšius davusiems asmenims būtų surašę administracinių teisès pažeidimų protokolus. Taigi darytina išvada, kad BK 225 straipsnio 2 dalies dispozicijoje nurodytas neteisèto neveikimo požymis nagrinëjamoje byloje nustatytas pagrịstai. Beje, kyšio davimo metu perduotų pinigų nesuradimas ir nepaèmimas netrukdo daryti išvadų dẻl kaltumo padarius BK 225 straipsnyje numatytas veikas ${ }^{24}$.

23 Lietuvos Aukščiausiojo Teismo Baudžiamųjų bylų skyriaus 2012 m. spalio 30 d. nutartis baudžiamojoje byloje Nr. 2K-P-178/2012.

24 Lietuvos Aukščiausiojo Teismo Baudžiamųjų bylų skyriaus 2012 m. spalio 30 d. nutartis baudžiamojoje byloje Nr. 2K-P-178/2012. 


\section{Išvados}

Valstybès tarnautojui prilygintas asmuo baudžiamąja teisine prasme negali būti prilygintas valstybės tarnautojui, o valstybès tarnautojo ir jam prilyginto asmens sąvokų turinys turi būti aiškinamas sistemiškai vadovaujantis ir kitais teisės aktais, nustatančiais jų funkcijas, teises, pareigas ir igaliojimus.

Kyšiu pagal BK XXXIII skyriaus normų taikymo praktiką gali būti bet kokios turtinio pobūdžio naudos siekimas (pvz.: neatlygintinai naudotis įmonès turtu, teikiamomis paslaugomis, ịsigyti turtą sumažintomis kainomis, gauti jo iš kitų asmenų), tariamos ar tikros civilinės sutartys su paperkamuoju, galimų turtinių nuostolių išvengimas ir pan. Kyšio suma minètame BK skyriuje, išreikšta MGL dydžiu, turi būti nurodoma ir vertinama labai tiksliai, kadangi tai yra vienas iš veikos kvalifikavimo kriterijų. Tuo tarpu teisiamajam asmeniui skiriant bausmę, sumos, artimos 1 MGL arba 250 MGL, kartu su kitomis byloje nustatytomis aplinkybemis gali būti vertinamojo pobūdžio, siekiant bausmès individualizavimo tikslų.

Sprendžiant veikų kvalifikavimo pagal BK 225, 227 straipsnio 1 arba 2 dalis klausimą, būtina byloje nustatyti valstybès tarnautojo ar jam prilyginto asmens veiklos, kuri tampa korupcinio elgesio objektu, teisètumo ribas. Jei valstybès tarnautojas ar jam prilygintas asmuo, pažadèjęs priimti kyši arba ji prièmęs, susitaria dèl teisèto veikimo, tačiau, be sutartų veiksmų, atlieka ir neteisètus, jis negali būti traukiamas baudžiamojon atsakomybèn pagal BK 225 straipsnio 2 dali.

\section{Literatūra}

Lietuvos Respublikos teisingumo ministerija. Teikimas dèl teisès aktų projektų. 2010-10-01, Nr. (1.5.)7R-8417.

Lietuvos Aukščiausiojo Teismo Baudžiamųjų bylų skyriaus $2008 \mathrm{~m}$. spalio $28 \mathrm{~d}$. nutartis baudžiamojoje byloje Nr. $2 \mathrm{~K}$ P-181/2008.

Lietuvos Aukščiausiojo Teismo Baudžiamųjų bylų skyriaus $2009 \mathrm{~m}$. vasario $10 \mathrm{~d}$. nutartis baudžiamojoje byloje Nr. $2 \mathrm{~K}$ 7-48/2009.

Lietuvos Aukščiausiojo Teismo Baudžiamųjų bylų skyriaus teisejjų kolegijos $2012 \mathrm{~m}$. vasario $7 \mathrm{~d}$. nutartis baudžiamojoje byloje NR. 2K-24/2012.

Lietuvos Aukščiausiojo Teismo Baudžiamųjų bylų skyriaus 2012 m. spalio $30 \mathrm{~d}$. nutartis baudžiamojoje byloje Nr. 2KP-178/2012.

Lietuvos Aukščiausiojo Teismo Baudžiamųjų bylų skyriaus 2012 m. gruodžio 18 d. nutartis baudžiamojoje byloje Nr. 2K-666/2012

Lietuvos Aukščiausiojo Teismo Baudžiamųjų bylų skyriaus 2013 m. kovo 19 d. nutartis baudžiamojoje byloje Nr. 2K160/2013.

Lietuvos Aukščiausiojo Teismo Baudžiamųjų bylų skyriaus $2013 \mathrm{~m}$. balandžio 9 d. nutartis baudžiamojoje byloje Nr. 2K-191/2013

Lietuvos Aukščiausiojo Teismo Baudžiamųjų bylų skyriaus 2013 m. gruodžio 
10 d. nutartis baudžiamojoje byloje Nr. 2K-540/2013.

Lietuvos Aukščiausiojo Teismo teisèjo Vytauto Greičiaus atskiroji nuomonè dèl Lietuvos Aukščiausiojo Teismo Baudžiamųjų bylų skyriaus teisèjų kolegijos $2012 \mathrm{~m}$. vasario $7 \mathrm{~d}$. nutarties Nr. 2K-24/2012.

Teismų praktikos skiriant bausmes už nusikalstamas veikas valstybès tarnybai ir viešiesiems interesams (Baudžiamojo kodekso 225, 226, 227 ir 228 straipsniai) tyrimas [interaktyvus]. [žiūrèta 2013-12-19]. <http://www2.lat.lt/lat_ web_test/4_tpbiuleteniai/senos/nutartis.aspx?id=34914>.

Duomenys apie nusikalstamumą Lietuvos Respublikoje. Užregistruotos ir ištirtos nusikalstamos veikos (Forma 1Ž) 2004-2012 m. [interaktyvus]. [žiūrèta 2014-03-18]. <http://www.nplc. lt:8000/asis/>.

Anotacija. Darbe nagrinėjami kai kuriu korupcinio pobūdžio nusikalstamu veiku kvalifikavimo probleminiai aspektai. Analizuojamas valstybès tarnautojui prilyginto asmens teisinis vertinimas, tarpininkavimo instituto turinys kyšininkavimo bylose, aptariami aktualūs teismu praktikos aspektai skiriant bausmes už korupcinio pobūdžio nusikalstamas veikas.

Reikšminiai žodžiai: korupcija, korupcija privačiame sektoriuje, teismų praktika, kyšis, papirkimas, valstybès tarnautojui prilygintas asmuo.

\title{
ACTUAL ISSUES ON JUDICIAL PRACTICE IN CRIMINAL PROCEEDINGS IN RESPECT OF CASES CONCERNED WITH CORRUPTION RELATED CRIMES
}

\author{
Artūras Petkus \\ Mykolas Romeris University, Lithuania
}

Summary. A significant number of changes in Articles of the Criminal Code of Lithuania (hereinafter - C.C.) was made in the year 2011. Some important changes were made in chapter XXXIII of the C.C., providing criminal liability for crimes and misdemeanors against the civil service and the public interest. The essence of the above mentioned changes is the objective to reconcile the rules of the C.C. with the recommendations of European Union institutions report, as well as to ensure the effectiveness of the criminal law. Though the role of development, consideration and adoption of legal norm is a very important process, but the entry into force of the Law itself does not guarantee the effectiveness and proper functioning of the rules as well as regulation of social relations. Another very important stage - legal practice - is directly related to the implementation of justice and judicial practice, the consistency and 
quality of the content is becoming one of the main preconditions for the effectiveness of the application to the Criminal Law.

In this paper, the jurisprudence of Lithuanian courts in the field of corruption related crimes is analysed. If the dynamics of passive bribery (Article 225 of the C.C.) in comparison with active bribery (Article 227 of the C.C.) have been analysed during the last decade, it can be tracked that the number of recorded acts of active bribery has increased almost 10 times, while the number of recorded acts of passive bribery has increased about 2 times. There is no ground for a priori opinion that persons have become much more likely to bribe civil servants or persons equivalent thereto. The background for such dynamics could be changes in priorities of law enforcement institutions, etc. Such situation has inspired the overview of some problematic issues in jurisprudence of Lithuanian courts, which relates both to the practical challenges in application of criminal law (qualification of corruption-related offenses, evaluation of evidence and arguments, etc.) and the challenges of criminology (the preventive effect of reaction of state institutions to corruption, etc.).

Keywords: corruption, corruption in private sector, judicial practice, bribe, active bribery, public servant or a person equivalent thereto.

Artūras Petkus, Mykolo Romerio universiteto Teisès fakulteto Baudžiamosios teisès ir kriminologijos katedros docentas. Mokslinių tyrimų kryptys: korupcijos tyrimai, priežastingumas, prevencija, korupcijos daroma žala, atskirų nusikalstamumo rūšių kriminologine charakteristika, viešasis saugumas, nusikaltèlio asmenybė, kriminalinė subkultūra.

Artūras Petkus, Mykolas Romeris University, Faculty of Law, Institute of Criminal Law and Procedure, Associate Professor. Research interests: corruption surveys, causation, prevention, damage of corruption, criminological characteristics of particular kinds of crimes, public safety, personality of criminal, criminal subculture. 